\title{
The ships that headed north - an archaeological perspective
}

\author{
MIKE BELASUS
}

Belasus, M. 2019. The ships that headed north - an archaeological perspective. AmS-Skrifter 27, 175-186, Stavanger. ISSN 0800-0816, ISBN 978-82-7760-183-0.

\begin{abstract}
Information on ships that were used for the North Atlantic trade, mainly from Hamburg and Bremen, is scarce and, to date, has been completely derived from historical documents. This is problematic because the terms used for ship types do not represent technical definitions. As there is currently no direct archaeological evidence for the ships that headed north, finds of ships and ship timbers from other areas had been considered to offer a first glance into shipbuilding and the mechanisms of change in building methods. Two main building methods can be distinguished in the medieval period for sea-going and coastal craft: the bottom-based Bremen-type shipbuilding method and clinker shipbuilding methods. The new carvel shipbuilding method was established in the late fifteenth century in north-west Europe. The archaeological evidence shows that there was no immediate change over but that in many cases, there was instead a convergence to achieve flush carvel-built hulls. Considering the Bremen-type with its flat bottom and limited sailing abilities and the fact that the German merchants only started to participate in the North Atlantic trade in the late fifteenth century, the question arises of whether there were other technical issues that prevented them from this enterprise until they managed to gain the knowledge required to build ocean-going vessels that could withstand a journey of several weeks across the North Sea and Norwegian Sea.
\end{abstract}

Mike Belasus, Deutsches Schifffahrtsmusem, Leibniz-Institut für maritime Geschichte, Hans-Scharoun-Platz 1, D-27568 BREMERHAVEN, GERMANY. E-mail: belasus@dsm.museum

Keywords: ships, shipping, ship archaeology, trade, technology, technology transfer

\section{Prologue - from cog to hulk to carvel?}

The large sea-going vessel of the Hanse was called the 'cog'. The larger 'hulk' vessel emerged in the middle of the fifteenth century, which had merged with the cog; although it could grow in size, the 'hulk' superseded the 'cog'. Carvel-built ship types very rapidly replaced the 'hulk' by the end of the century, having emerged from the fusion of 'cogs' with 'other' ship types in southern Europe towards the end of that century. ${ }^{1}$ This hypothesis was suggested by German historians on the basis of an evolutionary attempt to evaluate the written indications for ship types from historical documents and contemporary depictions during the first half of the twentieth century. ${ }^{2}$ This hypothesis suggested that the change of the main ship type used in northwest Europe was indicated by the change of the main terms used for large cargo vessels in the documents and thus equated the word with a technical definition. The inversion of this argument would be the identification of technical definitions for each ship type in the archaeological context as the main task of ship archaeologist, but is it that simple, and what would it be good for? ${ }^{3}$

In fact, the questions about the ships on which German merchants, mainly from Bremen and Hamburg, headed north across the stormy Atlantic seas to trade mainly for stockfish are not as easy to answer as might be expected. The information on this topic gathered by historians is scarce, leaves many things in the dark or obscure and occupies only a few pages. Nevertheless, some information has already been extracted from the historical documents. Thus, we know that the ships left from their harbours in the southern North Sea region by the middle of March to early April and that they arrived at their destination approximately one month later. During the sixteenth century, approximately 25 of them headed for Iceland each year. It has been told 
that on average 36 men sailed on each vessel and even how some of the ships were named. Their average size of cargo capacity has been mentioned to have been approximately 60 last or 120 metric tonnes, and even terms used for different ship types are given: 'Holk', 'Kogge', 'Kraffel', 'Bollich' and 'Bojert'. ${ }^{4}$ Although this information does not seem to be very reliable, upon closer inspection it causes confusion rather than enlightenment. Regarding the ship types, we have no information about which technical parameters made a ship a certain ship type. Was it the shape, the size, the cargo or the area of navigation? The German historian Ernst Baasch, who is often cited for information on the Hamburg trade with Iceland, showed us that even the medieval contemporaries were not clear about this. He referred to the case of Lutke Sten's ship, which was attacked by the English on Iceland in 1486. In the course of the action, one and the same vessel was called 'cog' by the party from Hamburg, 'holk' by the English opponents and 'small carvel' again by a Hamburg chronicler. ${ }^{5}$ This kind of inaccuracy is not an exception. In two messages warning the merchants of Wismar of pirate activity in 1422, for example, a vessel was described as a 'kreyer' in one case and as an 'ewer' in the other. ${ }^{6}$ There is nothing like an official and reliable medieval or early modern classification for ships. Instead, we are reminded of Plato's words once more, who taught some 2500 years ago: a word is not so identical to a thing that we would no longer have to look at the thing.? The early German researchers on this topic, historians Bernhard Hagedorn and Walter Vogel, were aware of this problem considering ship types but, nevertheless, tried to give technical definitions. Later, after World War II, other researchers such as the historian Paul Heinsius and the archaeologist and art historian Detlef Ellmers picked up on this topic but did not see any reason to doubt the possibility of finding technical definitions for historically derived terms for ship types. ${ }^{8}$ Their analysis focused mainly on the term 'cog', which has been seen as the main ocean-going cargo carrier of the Hanse. Factually, this interpretation was mainly based on the political issues of German historians during the late nineteenth and early twentieth centuries, in connection with the German empire's navy policy. ${ }^{9}$ For the mentioned reasons, it is not surprising that there have been some critical arguments against the methods used in 'ship-type research'. ${ }^{10}$ Today, most archaeologists agree that the term 'cog' must be understood as a purely archaeological technical term within archaeology and that it must not be confused with the same term mentioned in the historical sources. ${ }^{11}$
Others even demand a change of the term in archaeology to prevent further confusion. ${ }^{12}$

Another imprecision within the historical information was clarified by Thomas Wolf and concerns the tonnage or cargo capacity of the medieval ships. Although it was mentioned that the average vessel heading north was approximately 60 lasts, we have to be aware that this judgement was not made on the base of a reliable measuring method. A reliable method for this purpose was not in use until the twentieth century. Instead, it was rather a judgement by feeling and experience and was often only used to give a vague impression of a ship mentioned by the author of a document. ${ }^{13}$

The key to reliable information about the technical abilities of the ships of the late medieval and early modern period, their development and their capabilities is the ships themselves. This is again not new, but dates to the very beginnings of historical ship research in Germany around 1900, when there were no documented ship finds of the considered period available. ${ }^{14}$ Today, we have a noteworthy number of documented late medieval and early modern ship finds, and many ship timbers have been found during town excavations that can shed light on the development of shipbuilding. Still, we have to make restrictions about the vessels that were participating in the trade across the North Atlantic because there are no documented shipwrecks of the late medieval and early modern period documented at the destinations of the Faroes, Shetland or Iceland. Therefore, we have to base future research on the material that is available to us in other regions in the realm of the Hanse.

\section{Medieval shipbuilding in the realm of the Hanse - innovation by contact?}

What does archaeological evidence for ships of the Hanse look like? Because we have no ship finds from the North Atlantic destinations, the next step is to look for ship remains in the vicinity of Hamburg and Bremen, but even there, a closer look causes disappointment. From Hamburg, we have evidence of one sea-going vessel from the late sixteenth to the early seventeenth century. ${ }^{15}$ Apart from this, there is hardly any archaeological evidence for shipping. In Bremen, the case seems to be different. A number of shipwrecks were found over the past fifty years, but most of them are inland watercraft or were built for a fluvial-maritime environment. An explanation for this can be found in the geography 


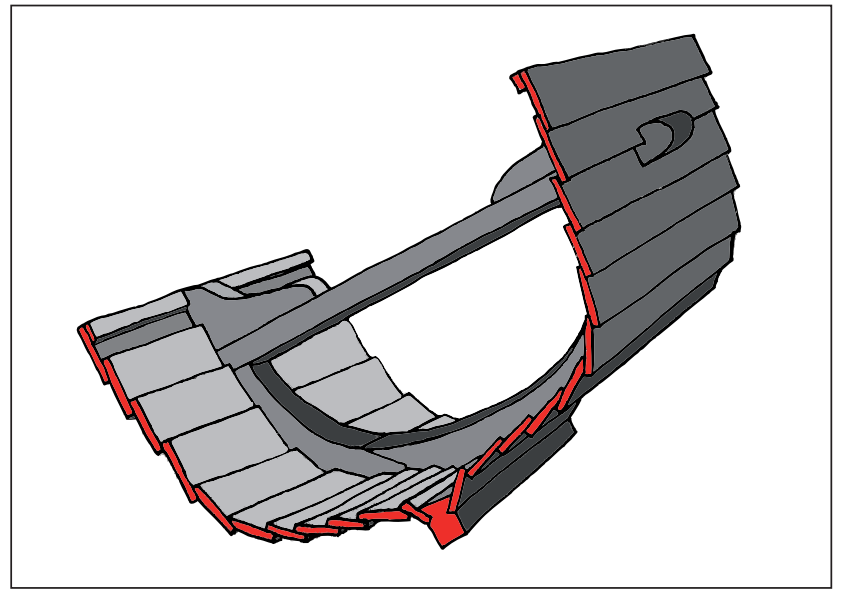

Fig. 1. Schematic cross-section of a clinker built vessel.

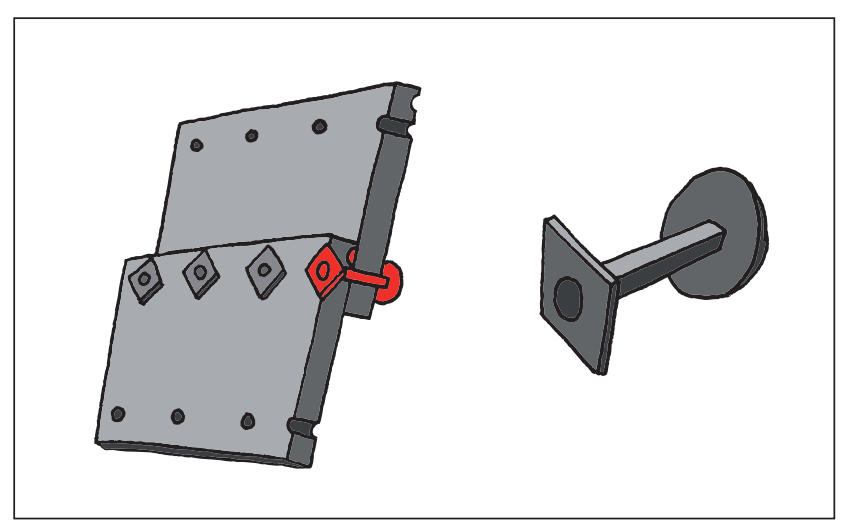

Fig. 2. Schematic view of the interconnection of the clinker hull strakes by rivets using iron nails from the outside riveted over a rhombic rove on the inside.

of these towns. Neither Hamburg, nor Bremen is situated directly on the coast. While the distance from Bremen to the North Sea is approximately $70 \mathrm{~km}$ down the river Weser, the distance from Hamburg down the river Elbe is approximately $90 \mathrm{~km}$. The North Sea coast around the mouths of the rivers offers no wrecks of the considered period at all.

The situation is very different on the German Baltic coast, in the vicinity of the Hanseatic towns of Lübeck, Wismar, Rostock, Stralsund and Greifswald. Although the number of detailed documented shipwrecks is limited compared to, for example, the Danish medieval ship finds, many ship timbers have been found in secondary use during town excavations. ${ }^{16}$ A careful analysis of these timbers and the information gathered from the existing ship wrecks gives us an important insight into the mechanisms of the development of shipbuilding methods in the medieval and early modern period and might give us an idea about the ships that headed north and those that might not have been able to sail the North Atlantic.
Two different shipbuilding methods can be found within the late medieval ship archaeological material from the south-west Baltic coast: the clinker method and the so-called cog-building method, which is called the Bremen-type building method in the following for the above-mentioned reasons and referring to the ship find that was the origin of the current technical definition. ${ }^{17}$ The clinker shipbuilding method has a long tradition in Europe and can be traced all the way from Scandinavia to the west coast of the Iberian Peninsula (Fig. 1). First evidence for this method dates back to the fourth century, and ships of this building method type evidently also sailed the Mediterranean Sea in the fifteenth century. ${ }^{18}$ The building started with the laying of the keel and erecting the stem and the sternpost on each side of it. On this 'backbone' of the ship, the hull planking was attached starting at the keel. During this process, each new strake of planks overlapped the previously attached one on the upper outside face. To water tighten the hull luting material, animal hair or moss soaked in wood tar was placed between the planks before they were connected. The choice for the building materials depended largely on their availability. The shape of the hull was determined during the building process by adjusting the bevel of the overlap, the so-called lands, following a rather organic and threedimensional idea of a ship. All strakes were connected to each other. Within the material from the Southwest Baltic, which dates from the eleventh to the fifteenth century, the strakes were connected by using iron rivets (Fig. 2) or wooden pegs. Iron rivets consisted of a nail hammered through a drilled hole from the outside to the inside. On the inside, the shaft of the nail was put through a rectangular rove. When the tip of the nail was removed, the remaining part of the nail's shaft was hammered flat - riveted. Only when the hull had reached a considerable height were the inner timbers inserted into it and attached to the outside planking by treenails. These timbers, transversal frames and longitudinal stringers gave strength to the shell-first built hull of the vessel.

When we approach the topic of clinker shipbuilding and shipping in the North Atlantic, we also have to take a close look at the ships of the mariners who sailed up to the north before the Germans: the Norwegians and the English. The Norwegians held the monopoly for the Iceland trade for a long time, and their shipbuilding was conducted using the clinker method. An early example of such a trading vessel that might have sailed from Norway is the so-called Big Ship from Bergen, for which pine timbers were cut in the 


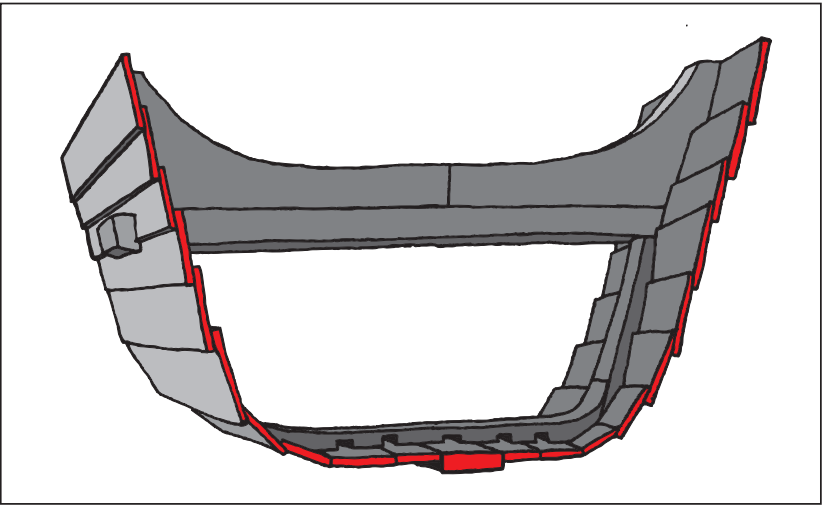

Fig. 3. Schematic cross-section of a bottom-based built ship of the Kollerup-Bremen type.

winter of the year $1187 / 88 .{ }^{19}$ Although the evidence for this ship comprises only a few separated ship timbers re-used in the foundations of buildings at the site of Bryggen, the German wharf, it reflects the ability of Norwegian shipwrights to build sturdy and, for their time, extraordinary large cargo vessels. Although the reconstructed length of the ship of approximately $30 \mathrm{~m}$ may be hypothetical, the width of approximately $9 \mathrm{~m}$ is evident in the floor timbers and crossbeams that were found. Until today, this ship find with its enormous dimensions was unique in the high medieval context of Northwest Europe.

Other ship finds from the Norwegian West coast dating to the late medieval period predominately represent clinker-built vessels. ${ }^{20}$ In addition, the English mariners, mostly those from Bristol, had a long tradition of sailing the open ocean in connection with their trade with France, the Bay of Biscay and the southern Iberian Peninsula but also to the north. Although there is no direct evidence for the English ships sailing the northern route, there are examples of ship finds of the fourteenth and fifteenth centuries that were most likely employed on the southern trading routes. They might not all be of English origin, but they are all large clinkerbuilt vessels made for the rough Atlantic conditions. ${ }^{21}$ Other vessels such as the clinker-built Grace Dieu of Henry $\mathrm{V}$ from the first quarter of the fifteenth century confirm the English shipwrights' experience and skills
A

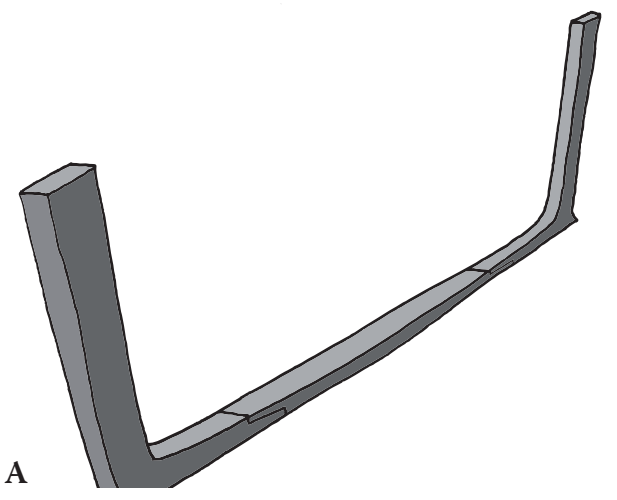

C

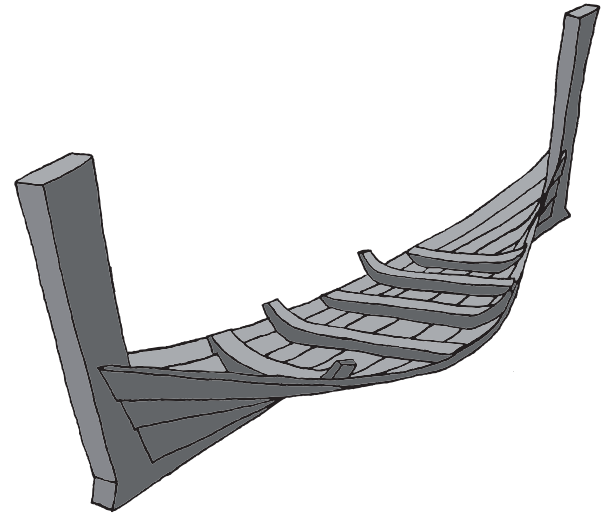

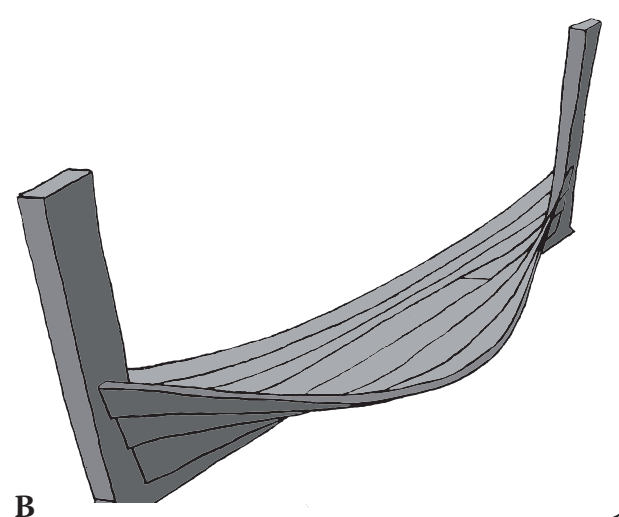

B

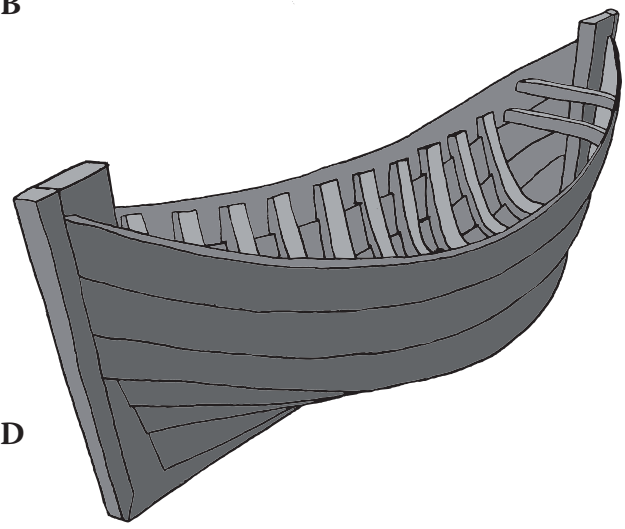

Fig. 4a-4d. Schematic view of the building-stages of the bottom based Kollerup-Bremen shipbuilding method: a) Erection of stem and stern hook connected to the central keel-plank. b) Construction of the bottom-base from edge to edge joined bottom planks that are only overlapping towards stem and stern, to which they are attached in an almost vertical angle. c) Stabilization of the bottom-base with floor-timbers. d) Building up the ship's sides in clinker fashion and fitting out the finished shell with internal frame timbers and longitudinal reinforcements. 
in building ocean-going ships that had been gathered over generations. This ship had enormous dimensions of more than $60 \mathrm{~m}$ in length and approximately 15 $\mathrm{m}$ width and was built as a floating castle or fighting platform in a specific political situation during war with France. It was a tactical base made for the operation of several hundred archers and other soldiers. By no means would it have been operated in a profitable way as a merchant ship because 200 mariners were required to handle the vessel. ${ }^{22}$ Still, once again, this ship highlights war as a driving factor behind technological developments, a fact that has not changed.

The Bremen-type building method can be traced back to the middle of the twelfth century (Fig. 4). Its material evidence was found in an area from Flanders in the west to Poland in the east and towards the north to the Skagerrak region, south-east Sweden and southern Finland. Fragments of ship timbers suggest the presence of Bremen-type ships also as far north as Bergen and east as Estonia. ${ }^{23}$ The basic construction started with a thick keel plank, to which angled timbers were connected to each end to form a transition to the straight stem and sternpost (Fig. 4a). On each side of the keel plank, the floor planks of the hull were laid next to each other without overlapping. These are bent towards the posts at the ends of the ship to be connected to them. Therefore, they overlap only towards the ends of the hull (Fig. 4b). The floor planks were preliminarily connected by cleats that were nailed to the inside faces of the planks. In this way, a bottom-base was created that determined the shape of the upper part of the hull. After stabilizing this part of the vessel with floor timbers, the lower part of the frames (Fig. 4c), the side planking, was added in an overlapping manner (Fig. 4d). These planks were connected by iron nails, which were hammered through drilled holes in the overlaps and double clenched on the inside. The tip was hammered back into the wood (Fig. 5). To water tighten the vessel, the caulking material, in most cases, tar-soaked moss, was pressed into the seams between the planks after they were connected. To keep this material in place, wooden laths were placed on top of the seams and fixed with iron clamps, which are also known as sintels. After the hull had reached its height, the remaining frame and longitudinal timbers were added.

A building method that shares many features with the Bremen-type building method is that of bottombased built barges (Fig. 6). They have their origin in the Roman provinces. For their building, the floor-planks were laid edge to edge next to each other. This bottom

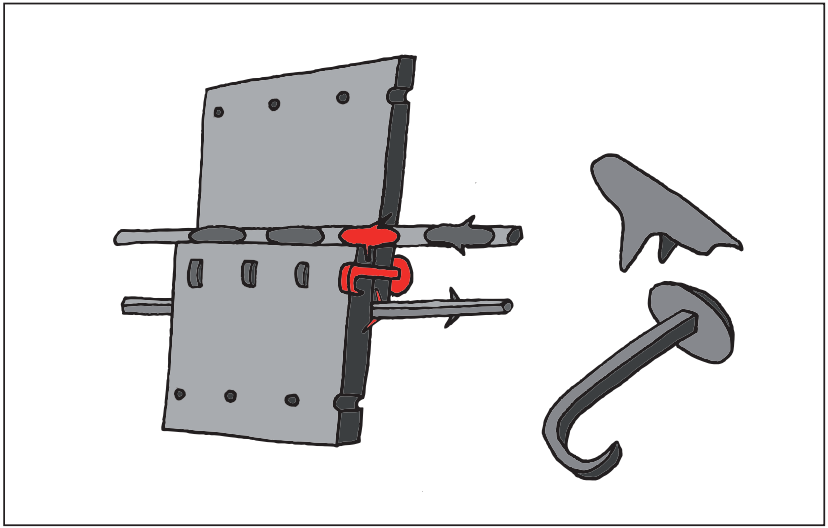

Fig. 5. Schematic view of the strake interconnections in the bottom-based built Kollerup-Bremen shipbuilding method by double clench iron nails and the securing of the sealing material by caulking-lath fixed with iron sintels.

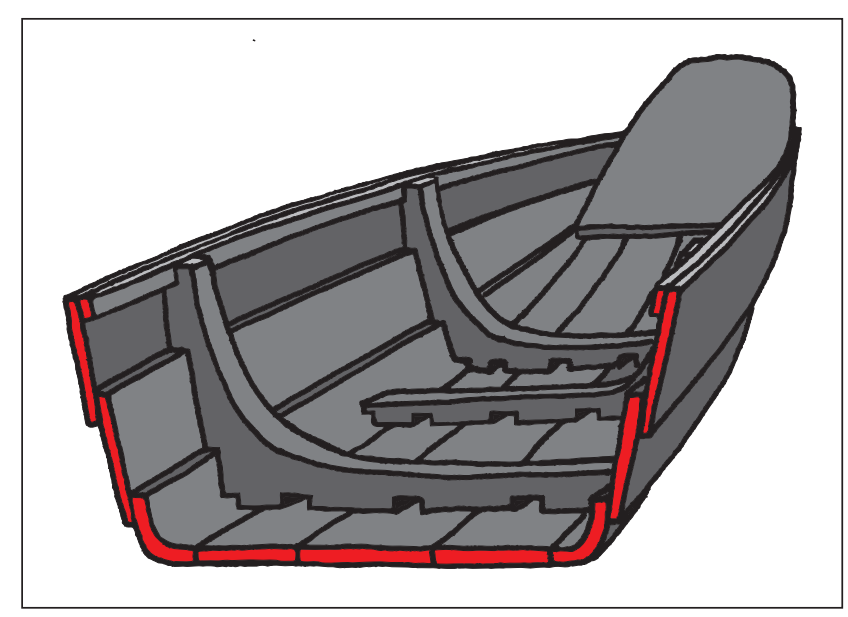

Fig. 6. Schematic cross-section of a bottom-based built inland craft with flush, edge to edge joined bottom planks, L-shaped transition planks and sides in clinker fashion.

plate was bent upwards at the ends and connected by the floor timbers. The transition to the sides was produced by planks, which were carved with L-shaped cross-sections. The first plank on each side was attached to the transition-planks with treenails. The following strake overlapped the first one on the outside. In the high and late medieval period, the second strake was connected to the first by the already described double-clenched nails. Before that time, the connections between the strakes had often been made using trenails. The water tightening was also conducted in the same way as described for the Bremen-type building method.

The late medieval archaeological evidence for ships confirms more than one dominant method of shipbuilding. Bremen-method and clinker-built ships existed at the same time, and the results of 
dendro-provenancing confirm the co-existence of their building in the same geographical area. There are ship finds of both building methods in the fourteenth and fifteenth centuries, which represent the same size of vessel and the same type of purpose as long-distance cargo vessels. A unique fourteenth-century site in Stralsund even revealed a ship repair workshop, where ships of all building methods were evidently repaired. ${ }^{24}$ The evaluation of the currently available archaeological material gives another interesting insight. Before the new German settlers from Westphalia introduced the Bremen-type and bottom-based barge building methods along the southern Baltic coast, the Slavic people who had settled this area used the clinker shipbuilding method. ${ }^{25}$ Their clinker building method was very similar to the one applied in Scandinavia with only a few differences. One of the main differences was the predominance of the use of wooden pegs to connect the overlapping strakes. However, typical Scandinavian vessels are evident on the southern Baltic coast, and in some cases, iron rivets can be traced in the supposedly regional southern Baltic shipbuilding technique. ${ }^{26}$

With the arrival of the settlers from the west and the funding of German towns along the southern Baltic coast during the thirteenth century, the new ship building methods spread, but the southern Baltic clinker shipbuilding method continued to exist, even in the newly founded German towns, until the end of that century. This can be seen, for example, in Stralsund. ${ }^{27}$ Rivets or sintels were only used in repairs. In theory, there could have been a change to the simpler and economic connection with double-clenched nails, but the change that finally occurred was a switch to the riveting technique that had been known in this region since Slavic times. The analysis of the available material shows no direct interchange between the new and old shipbuilding techniques. The builders of both methods seem to have kept, for the most part, to themselves, and the necessary changes often have the character of internal inventions rather than a transfer of technology.

This behaviour in shipbuilding is also reflected in the high medieval ship finds from the region of medieval Denmark. The clinker-built 'Karschau' ship from the Schlei firth in Schleswig-Holstein, Germany, was built in the Little Belt region in 1140 in the same region, where almost at the same time, in approximately 1150, the Bremen-type ship find of 'Kollerup' was built. ${ }^{28}$ Except for a few iron sintels that were used in a repair, the 'Karschau' ship matches almost entirely the technical features of Viking Age clinker ships. ${ }^{29}$ Another example is the 'Möweninsel' ship that was found in the Schlei firth, similar to the 'Karschau' ship. It was built after 1163, most likely on the west coast of Sweden..$^{30}$ It gives a good impression of how the necessary alterations within the building concept were coming from within a shipbuilding method. Here, for example, the 'biti' called crossbeams, an indicative feature for the Nordic clinker shipbuilding method, were relinquished in favour of a more spacious cargo hold. Decorative mouldings were also abandoned, for the most part, to simplify the building process, but the remaining features of the vessel still closely fit the Nordic clinker shipbuilding method, as it is known from the Viking Age.

The image we get from the archaeological record is that of the coexistence of different shipbuilding methods next to each other. Changes are present as well but not because of the simple contact of different building methods. If there was no reason for a change, then change did not simply occur: each ship builder's method was the best for himself, as it was handed down from one generation to the next. This connection also shows us that shipbuilding methods and, moreover, the traditions within these methods must have been linked to certain communities in which the knowledge was kept and forwarded to the next generations. These traditions were more than insurance for the survival of the trade but were insurance for craftsmen to create seaworthy ships.

The coexistence of both shipbuilding methods in the same region also seems to be evident for the southern North Sea region in the archaeological record of the Netherlands. ${ }^{31}$ It continued here until modern times. ${ }^{32}$ The German part of the North Sea coast for now might lack the evidence, but as we all know: absence of evidence is not evidence of absence.

\section{From late medieval to early modern shipbuilding - an incident in history?}

When we try to understand shipbuilding as an act of humans based on knowledge handed down by the process of tradition within a defined community, the idea of a simple adoption of a new shipbuilding method at the turn from medieval to early modern times becomes doubtful. The advent of the carvel-built full-rigged ship in the north of Europe is occasionally described as a sudden occurrence, an incident in history. Regarding the realm of the Hanse, this was historically linked to the story of the 'Peter von Danzig'. This ship, described in the documents as a 'the big carvel' and originally 


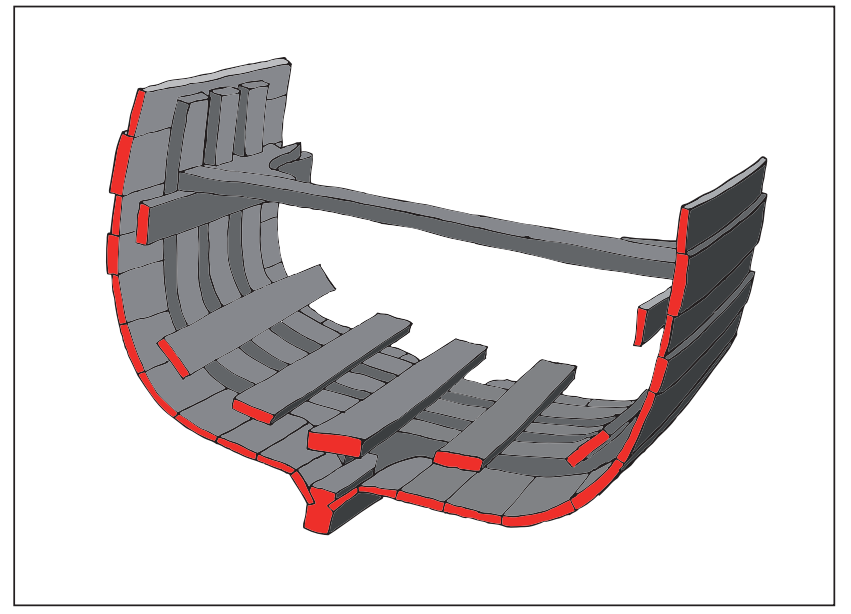

Fig. 7. Schematic cross-section of a carvel built vessel.

named 'Pierre du La Rochelle', was given up by her owners at Danzig in 1462 after lightning struck the ship. Later, it was taken over by the town council, and the shipwrights who were inspecting and repairing the vessel thereby learned how to build carvel ships. ${ }^{33}$ The idea that new technical solutions would have been just taken over to replace old building traditions after generations of handed-down shipbuilding experience seems to be very unlikely. Another aspect against this theory is the difficulties of giving a ship's hull its shape. This is a feature of the building process and is considered almost impossible to learn just by inspecting the final product. Clinker ship builders used a set of measurements, the bevels of the overlap and the natural curvature of the planks to design their hulls. In the Bremen-building procedure, the bottom-shell, built by laying the planks next to each other and bending them upwards towards the centreline to attach them to the posts, defined most of the ship's shape. A carvel-built ship where the planks are not attached to each other does not reveal the ship builder's technique of shaping the hull such that the observer can reproduce it.

The carvel technique (Fig. 7) had its origin in the Mediterranean, where it was developed from a shellfirst to a frame-first construction technique. ${ }^{34}$ It is believed that this building method spread towards the north of Europe during the fifteenth and sixteenth centuries, but this development cannot be explained with a simple model of taking over a new method and replacing the old one. In fact, there were several methods for achieving a flush-planked carvel hull. In the early modern period, at least two basic methods existed in northwest Europe: the frame-first building method, where the frames were the guidance for the hulls' shape, and the bottom-based or Dutch flush-building method, where the shell of the lower hull was built to a certain height before the frames were set in. ${ }^{35}$ The latter one has similarities to the Bremen-type building method, where the planks of the lower hull were preliminarily fixed together by wooden cleats nailed on the inside faces of the planking. These similarities were already noted by Fred Hocker, who considered it most likely that the bottom-based carvel building method was invented by the shipwrights of the Bremen-method. ${ }^{36}$ Christian Lemée even suggested that the wooden cleats, which were used for the preliminary connection of the lower strakes, also determined the shape or angle between them and could be re-used to duplicate a ship's hull. ${ }^{37}$

A closer look at the archaeological record seems to give some clues to support Hocker's theory. Although it was believed that sea-going ships of the Bremen-type were vanishing after approximately 1450, there is still archaeological evidence from the second half of the fifteenth century. The wreck 'Wismarbucht 6' from the German Baltic coast in Mecklenburg-West Pomerania, for example, was dated to after 1476. The timbers of the wreck were most likely cut in the catchment area of Riga. The find is not very well preserved, and most of the original timbers were most likely salvaged after the ship was abandoned in shallow water. The features of a flush bottom and overlapping side planking connected by double-clenched nails are still visible. Instead of caulking lath fixed with sintels to secure the caulking material in the seams, thin battens were nailed on top of the seams before the floor timbers were fixed on top of them. These were juggled over the battens (Fig. 8). The same way of water tightening the hull was observed on the wreck of the fluvial-maritime vessel 'Canche EP1' from the River Canche near Beutin in northern France. The timbers of this vessel were cut locally in $1425 / 26 .{ }^{38}$ Regarding the possibility of timber trade, it cannot be said with certainty where the 'Wismarbucht 6' was actually built, and the possibility of its origin in the Flanders region such as 'Canche EP1' should not be excluded.

The use of stronger battens instead of lath and sintels can possibly be explained by a change in the caulking technique. Wooden chisel-shaped tools were evidently used to press the caulking material into the seams of both ships of the Bremen-type method and bottombuilt barges during the fourteenth century. They were found with the Bremen ship and among ship timbers in Stralsund-Frankenhof. ${ }^{39}$ The finds of early caulking irons in the Netherlands date to as early as the fourteenth century. This tool, which was developed during the fifteenth and sixteenth centuries, is still used by 


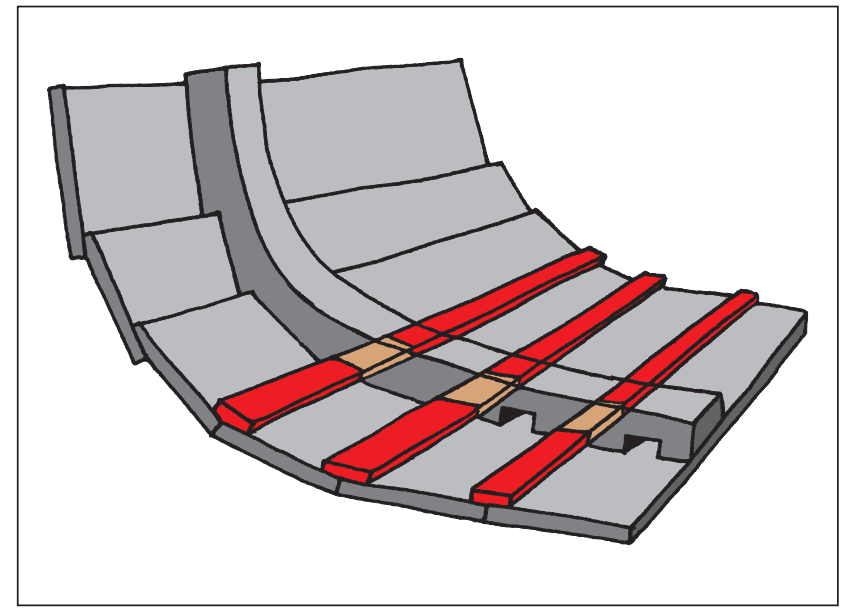

Fig. 8. Schematic view of the continuous plank seam covering with battens, as observed in the bottom-based built Bremen-type ship find 'Wismarbucht 6' from after 1476 AD.

boat builders today. ${ }^{40}$ Using such a tool made from iron increases the potential power for driving the caulking material into the seams between the planks. The battens covering the seams from the inside in 'Wismarbucht 6' and 'Canche EP 1' would have been an improvement to caulking a ship from the outside, a strong abutment to withstand the power of the caulking iron that allows a high degree of compaction of the caulking material without being hammered through the seams.

The covering of the seams with battens still follows the original medieval concept of overlapping as a guarantee for a watertight hull in Northwest Europe. The overlap was used to secure the sealing material in position. Making a carvel built hull with its unconnected flush outer planking watertight was therefore not an easy task for the medieval shipwrights of this region. This is expressed, for example, by the fact that during the introduction of the carvel building method in England, specialized caulkers had to be hired for this purpose. Additionally, when the 'Peter von Danzig' sailed against the English, the crew had serious problems with stopping the leaking hull from taking water, even though the ship had been rebuilt in Danzig before it set sail. ${ }^{41}$

Considering these difficulties, it is not surprising that a technical solution very similar to that of 'Wismarbucht 6' and 'Canche EP1' can be found in early modern carvel built ships from northern Europe. This is the case in the sixteenth-century wrecks of the 'Elephanten' and 'Mars' in Sweden and of 'Darss 44', 'Jasmund 7 Mukran', and 'Hamburg-Wittenbergen' in Northern Germany. Here, battens are used to cover the seams between the planks from the inside, but

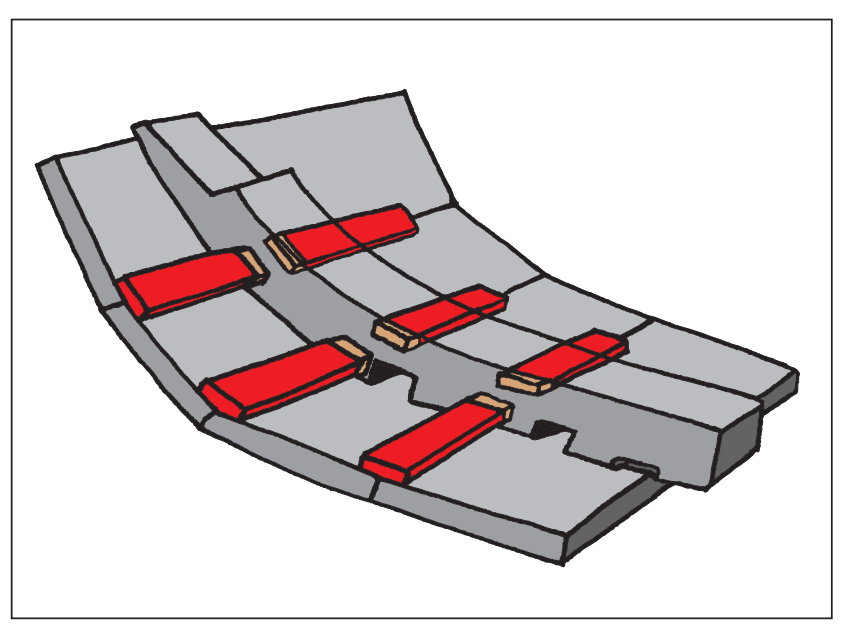

Fig. 9. Schematic view of the frame interrupted plank seam covering observed in different sixteenth-century carvel ship finds from Germany and Sweden.

these battens do not cover the entire length of the seams. Instead, they were inserted between the frames and held in place by being fitted into small notches on the outside face of the framing timbers (Fig. 9). On 'Jasmund 7' and 'Hamburg-Wittenbergen', the presence of plugged nail holes was confirmed. This feature confirms their construction in the bottombased carvel building method. In combination with the batten-covered seams, it makes the development of a carvel-building method on the basis of the bottombased Bremen-type shipbuilding method a believable process. Nonetheless, it was not the only way in which carvel shipbuilding was introduced in Northern Europe. The archaeological record shows that there were also endeavours among the clinker ship builders to build carvel ships. Some sixteenth-century carvel ships from Northwest Europe show common features of the clinker-building method. The sixteenth-century 'Hafnia' ship from Denmark, for example, has a t-shaped keel that is typical of Nordic clinker ships. In this case, even the garboard strakes were attached to the keel by iron rivets. The planks within the strakes were connected by horizontal-diagonal scarves. ${ }^{42}$ Horizontal-diagonal scarfs can also be found in the sixteenth-century 'Princess Channel/Gresham Wreck' from the Thames estuary, as one would expect in a clinker built vessel. In addition to these scarfs, a string of twisted animal hair was placed in a groove in the short top sides of the planks before these were covered by the planks of the following strake. ${ }^{43}$ The principle of this method is the same as in clinker shipbuilding. Here, the groove used to house the twisted string of caulking material was placed on the upper outside face 
of the planks and covered with the following strake in the overlap. It is difficult to say if the presence of these features in carvel-built ships is the result of an alternative development of a carvel shipbuilding method. It is more likely that shipwrights trained in the clinker shipbuilding method were building carvel ships under the supervision of a master shipwright of a carvelbuilding method. In this way, they introduced their own technical solutions into carvel shipbuilding of north-west Europe. The import of knowledge on carvel shipbuilding through the hiring of foreign master shipwrights is verified for many regions of north-west Europe and is the case for some towns in the Hanse, but not all ship builders of the old building methods had access to this foreign knowledge. ${ }^{44}$ This was often limited to royal dockyards or wealthy citizens. The archaeological record confirms that the shipwrights of the clinker building method did not retreat from the building of sea-going vessels, at least until the middle of the sixteenth century. Remains of large early modern clinker-built hulls have been found in the Netherlands and Sweden. ${ }^{45}$ It is even possible that clinker-built vessels were ships that were more capable of travelling the high seas. This could be the case, not only considering the ship finds on the Norwegian west coast, but also because the northerners during the Viking Age were the first to cross the North Atlantic and reach North America. ${ }^{46}$ However, ship finds of the Bremen-type are not known yet north of Bergen or west of the English Channel. The tests that were undertaken on the base of the 'Bremen' ship show a considerable leeward drift of the ship under sail, which could become dangerous along a rough lee coast or cause the ship to have difficulties in reaching its destination on a long journey across an open ocean. ${ }^{47}$ The method of determining the shape of the hull must have been a crucial reason for the shipbuilders to stick to their old building techniques. This becomes apparent with the existence of the so-called half-carvels. With this solution, the shipwrights seemingly adopted a principal of the bottombased carvel construction method into their clinker technique. Building half-carvel ships started with the traditional clinker building method. This enabled the builder to determine the shape of the underwater part of the hull, which is responsible for a large part of a vessel's sailing capabilities. After reaching the turn of the bilge where the transition from the floor to the sides occurs, the frames were put in, and the futtocks were erected to the height of the ship's sides. This enabled them to plank the upper part of the hull in a framefirst carvel way. This method might be traced to the late fifteenth century. ${ }^{48}$ In the archaeological record, it is evident from the second half of the sixteenth century onwards. ${ }^{49}$

\section{Epilogue - what do we want to know about the ships that headed north?}

When we consider the historical and archaeological information about shipbuilding during the late medieval and early modern period that has been gathered to date, it becomes difficult to accept an evolutionary or linear process in the development of sea-going ships. Instead, shipbuilding shows itself as the product of rational decisions of shipwrights within their own traditions and technical abilities and according to the demands on their trade. The development in shipbuilding in north-west Europe was rich in variations. Compared to the earlier changes, the developments in the late fifteenth and sixteenth centuries were even more intense, with a major goal of building ships with a flush outer planking. The advantages for the shipbuilders must have been crucial, and the presence of an immense economic pressure should be considered. The manifold solutions to build carvel hulls or at least halfcarvel hulls highlight the problems that shipwrights had with their non-written traditional methods that were learned with their eyes and ears and not from written sources. The diversity in shipbuilding again reminds us of the incident of Ludke Sten's ship on Iceland, which was called cog, holk and carvel by different sources. Questioning the use of technical definitions for historically derived terms for ships thus seems justified. In fact, this use causes confusion rather than enlightenment. Other questions would give us much greater understanding of the past. It is important to know, not how a certain ship was called but what it was used for, in which waters and by whom. How and for what reasons was shipbuilding altered, improved or simplified? These questions will lead us away from a purely technical observation of watercraft and will allow us to merge the pure material evidence with its social background and thereby shed light on the people who produced and used these material remains.

In this particular case, ships were needed to cross waters with very different conditions from those found in coastal areas or the Baltic Sea, where the main routes of the Hanse's trade had been before. What type of ship and what navigational skills were needed to cross the North Atlantic in a journey of several weeks? Were 
the old shipbuilding methods capable of accomplishing this task, or was the trade across the open ocean a driving force behind the development of shipbuilding in the Hanse's towns at the end of the fifteenth and early sixteenth century? The ships had to be not only seaworthy, but large enough to house crews and provisions for the duration of the trip, spare parts to repair the ship in emergencies and, last but not least, a cargo that made the effort and expenses worth the risk.

\section{Endnotes}

${ }^{1}$ Heinsius 1986, 252.

${ }^{2}$ Hagedorn 1914; Vogel 1915; Heinsius 1986.

${ }^{3}$ Ellmers 1979, 493.

${ }^{4}$ Hofmeister 2000, 41-44.

${ }^{5}$ Baasch 1889, 103.

${ }^{6}$ Wolf 1986, 21.

${ }^{7}$ Gessinger and von Rahden 1989, 559.

${ }^{8}$ Heinsius 1986; Ellmers 1979.

${ }^{9}$ Belasus 2017a.

${ }^{10}$ Varenius 1992; Maarleveld 1995; Weski 1999.

${ }^{11}$ Crumlin-Pedersen 2000, 239.

${ }^{12}$ Englert 2015, 110; Förster 2009, 234, 254; Weski 1999, 360-379.

${ }^{13}$ Wolf 1986, 20-29. See also Belasus, in press.

${ }^{14}$ Hagedorn 1914, 6; Vogel 1915, 465.

${ }^{15}$ Stanek 2011.

${ }^{16}$ Belasus 2012; Bill 1997.

${ }^{17}$ Englert 2015, 69f.

${ }^{18}$ Rieck 2013; Soberón et al. 2012.

${ }^{19}$ Christensen 1985; Christensen 2002.

${ }^{20}$ Auer and Maarleveld 2013; Nævestad 1998.

${ }^{21}$ Milne 2004; Adams and Black 2004; Nayling and Jones 2014; L'Hour and Veyrat 1994.

${ }^{22}$ Carpenter-Turner 1954; Friel 1993.

${ }^{23}$ Christensen 1985, 100f.; Mäss 1992.

${ }^{24}$ Grassel 2011.

${ }^{25}$ Belasus 2017b.

${ }^{26}$ Nakoinz 1998, 311-321.

${ }^{27}$ Kulessa 2005, 241-255.

${ }^{28}$ Daly 2007a, 72-78; 2007b, 155-166.

${ }^{29}$ Siegloff 2004, 120.

${ }^{30}$ Belasus 2004; Daly 2007a, $119 \mathrm{ff}$.

${ }^{31}$ Reinders 1979, 35-43.

${ }^{32}$ Schutten 2004.

${ }^{33}$ Lienau 1943.

${ }^{34}$ Pomey et al. 2012.

${ }^{35}$ Hocker 2004, 79; Adams 2013, 71.

${ }^{36}$ Hocker 2004.

${ }^{37}$ Lemée 2006, 141.

${ }^{38}$ Rieth 2013.

${ }^{39}$ Keweloh 1983, 7-10; Grassel 2011, 76.

${ }^{40}$ Hocker and Vlierman 1996, 82-85.

${ }^{41}$ Friel 1995, 173f.; Lienau 1943.

${ }^{42}$ Bill 1997, $232 \mathrm{f}$.

${ }^{43}$ Auer et al. 2009, 79-88.

${ }^{44}$ Hirsch and Vossberg 1855, 87; Lemée 2006, 59; Litwin 1991.

${ }^{45}$ Overmeer 2007; Svenvall 1994.
${ }^{46}$ Auer and Maarleveld 2013.

${ }^{47}$ Brandt et al. 1994.

${ }^{48}$ Hirsch and Vossberg 1855, 57.

${ }^{49}$ Eriksson 2008, 4-9.

\section{References}

Adams, J. 2013. A Maritime Archaeology of Ships. Innovation and Social Change in Medieval and Early Modern Europe. Oxford: Oxbow.

Adams, J. and Black, J. 2004. From rescue to research: medieval ship finds in St Peter Port, Guernsey. International Journal of Nautical Archaeology 33(2), 230-252.

Auer, J. and Maarleveld, T. (eds) 2013. Fieldwork Report Skjernøsund 3 Wreck 2011. Esbjerg: Syddansk Universitet.

Auer, J., Bangerter, R. and Mallon, F. 2009. The wreck of an Elizabethan merchantman from the Thames. A preliminary fieldwork report, in R. Bockius (ed.), Between the Seas. Transfer and Exchange in Nautical Technology. Proceedings of the Eleventh International Symposium on Boat and Ship Archaeology, 79-88. Mainz: RömischGermanisches Zentralmuseum.

Baasch, E. 1889. Forschungen zur hamburgischen Handelsgeschichte I. Die Islandfahrt der Deutschen, namentlich der Hamburger vom 15. bis 17. Jahrhundert. Hamburg: Herold.

Belasus, M. 2004. Das Möweninsel Schiff. Ein mittelalterlicher Schiffsfund aus der Inneren Schlei. Unpublished Diploma thesis, Kiel University.

Belasus, M. 2012. Abschlussbericht zum DFGForschungsprojekt: Schiffe und Schiffahrt während des hohen und späten Mittelalters in der südwestlichen Ostsee. Auswertung der archäologischen Quellen aus Mecklenburg-Vorpommern (unpublished report). Frankfurt am Main: Römisch-Germanische Kommission.

Belasus, M. 2017a. Historical ship archaeology in the shadow of historism - a German perspective, in A. Brooks and N. Mehler (eds), The Historical Archaeology of Nationalism and National Identity, 222-242. Gainesville: Florida Univerity Press.

Belasus, M. 2017b. Those bits and pieces from the Baltic shores - evidence for medieval shipping along the German Baltic Sea coast from the 12th until the 15th century, in W. Ossowski (ed.), The Baltic and Beyond. Change and Continuity in Shipbuilding. Proceedings of the $14^{\text {th }}$ Symposium on Boat and Ship Archaeology 2015, 33-38. Gdańsk: National Maritime Museum.

Belasus, M. in press. Does size matter? Some thoughts on the cargo capacity of German ships that sailed the North Atlantik, in N. Mehler (ed.), German voyages in the North Atlantic (c. 1400-1700). Leiden: Brill.

Bill, J. 1997. Small Scale Seafaring in Danish Waters AD 1000-1600. Unpublished PhD thesis, Copenhagen University.

Brandt, H., Hoheisel, W. D. and Hochkirch, K. 1994. Experimentelle Ermittlung der Segelleistung von einem 
originalgetreuen Nachbei der Hansekogge von 1380. Unpublished DFG-research project report. Berlin: Technische Universität.

Carpenter-Turner, W. J. 1954. The building of the Gracedieu, Valentine and Falconer at Southampton, 1416-1420. Mariner's Mirror 40(1), 55-75.

Christensen, A. E. 1985. Boat finds from Bryggen. The Bryggen Papers, Main Series vol. 1, 47-278. Oslo: Universitetsforlaget.

Christensen, A. E. 2002. The 'Big Ship' of Bryggen in Bergen: what can it tell us? Deutsches Schiffahrtsarchiv 25, 87-95.

Crumlin-Pedersen, O. 2000. To be or not to be a cog: the Bremen cog in perspective. International Journal of Nautical Archaeology 29(2), 230-46.

Daly, A. 2007a. Timber, Trade and Tree-rings. A dendrochronological analysis of structural oak timbers in Northern Europe, c. AD 1000 to c. AD 1650. PhD thesis, Syddansk Universitet.

Daly, A. 2007b. The Karschau ship, Schleswig-Holstein: dendrochronological results and timber provenance. International Journal of Nautical Archaeology 36(1), 155-66.

Ellmers, D. 1979. Schiffsarchäologie, in H. Jahnkuhn and R. Wenkus (eds), Geschichtswissenschaft und Archäologie. Untersuchungen zur Siedlungs-, Wirtschafts- und Kirchengeschichte, 485-516. Sigmaringen: Thorbecke.

Englert, A. 2015. Large Cargo Ships in Danish Waters 1000-1250. Evidence of specialised merchant seafaring prior to the Hanseatic period. Ships and Boats of the North 7. Roskilde: Viking Ship Museum.

Eriksson, N. 2008. An early 'half-carvel' in the northern Baltic. Maritime Archaeology Newsletter from Denmark 23, 4-9.

Förster, T. 2009. Große Handelsschiffe des Spätmittelalters. Untersuchungen an zwei Wrackfunden des 14. Jahrhunderts vor der Insel Hiddensee und der Insel Poel. Schriften des Deutschen Schiffahrtsmuseums 67. Kuden: Convent.

Friel, I. 1993. Henry V's Grace Dieu and the wreck in the R. Hamble near Bursledon, Hampshire. International Journal of Nautical Archaeology 22(1), 3-19.

Friel, I. 1995. The Good Ship. Ships, Shipbuilding and Technology in England 1200-1520. London: British Museum Press.

Gessinger, J. and von Rahden, W. 1989. Theorien vom Ursprung der Sprache. Berlin: de Gruyter.

Grassel, P. 2011. Mittelalterliche Schiffsholzfunde aus einem Gebäudefund des 14. Jh. vom Fundplatz StralsundFrankenhof. Unpublished Magister thesis, Kiel University.

Hagedorn, B. 1914. Die Entwicklung der wichtigsten Schiffstypen bis in das 19. Jahrhundert. Berlin: Curtius.

Heinsius, P. 1986. Das Schiff der hansischen Frühzeit. Cologne: Böhlau (second edition).

Hirsch, T. and Vossberg, V. A. 1855. Caspar Weinreichs Danziger Chronik. Ein Beitrag zur Geschichte Danzigs, der Lande Preussen und Polen, des Hansabundes und der Nordischen Reiche. Berlin: Stargardt.
Hocker, F. M. 2004. Bottom-based shilpbuilding in northwestern Europe, in F. M. Hocker and C. A. Ward (eds), The Philosophy of Shipbuilding. Conceptual Approaches to the Study of Wooden Ships, 65-93. College Station: Texas A\&M University Press.

Hocker, F. M. and Vliermann, K. 1996. A Small Cog, Wrecked on the Zuiderzee in the Early Fifteenth Century. Flevobericht 408. Lelystad: Nederlands Intituut voor Scheeps- en onderwater Archeologie.

Hofmeister, A. E. 2000. Hansische Kaufleute auf Island im 15. und 16. Jahrhundert, in Deutsch-Isländische Gesellschaft Bremerhaven/Bremen (ed.), KircheKaufmann-Kabeljau: 1000 Jahre Bremer Islandfahrt, 33-46. Staatsarchiv: Bremen.

Keweloh, H.-W. 1983. Kalfathölzer - Zur Interpretation Eines Beifundes der Hansekogge. Deutsches Schiffahrtsarchiv 6, 7-10.

Kulessa, B. 2005. Siedlungsgeschichte und Hafenentwicklung in der Hansestadt Stralsund vom Mittelalter bis zur frühen Neuzeit. Rahden: Leidorf.

Lemée, C. P. P. 2006. The Renaissance Shipwrecks from Christianshavn. An archaeological and architectural study of large carvel vessels in Danish waters, 15801640. Roskilde: Viking Ship Museum.

L'Hour, M. and Veyrat, E. 1994. The French medieval clinker wreck from Aber Wrac'h, in C. Westerdahl (ed.), Crossroads in Ancient Shipbuilding. Proceedings of the Sixth International Symposium on Boat and Ship Archaeology, Roskilde 1991, 165-80. Oxford: Oxbow.

Lienau, O. 1943. Das grosse Kraweel der Peter von Danzig: 1462-1475. Ein Beitrag zur Geschichte deutscher Seegeltung. Gdánsk: Rosenberg.

Litwin, J. 1991. The first Polish galleon and its construction register from 1570-1572, in R. Reinders and P. Kees (eds), Carvel Construction Technique Skeleton-first, Shell-first. Fifth International Symposium on boat and ship archaeology, Amsterdam 1988, 56-61. Oxford: Oxbow.

Maarleveld, T. J. 1995. Type or technique. Some thoughts on boat and ship finds as indicative of cultural traditions. International Journal of Nautical Archaeology 24(1), 3-7.

Mäss, V. 1992. A medieval ship from the Pärnu river. Eesti NSV Teaduste Akadeemia Toimetised, Humanitaar ja sotsiaalteadused, 293-98.

Milne, G. 2004. The fourteenth-century merchant ship from Sandwich: a study in medieval maritime archaeology. Archaeologia Cantiana 124, 227-264.

Nævestad, D. 1998. Lokaliserte Middelaldervrak i ØstNorge. Norsk Sjøfartsmuseum Årbok, 159-207.

Nakoinz, O. 1998. Das mittelalterliche Wrack von SchubyStrand und die Schiffbautraditionen der südlichen Ostsee. Archäologisches Korrespondenzblatt 28, 311-22.

Nayling, N. and Jones, T. 2014. The Newport Medieval Ship, Wales, United Kingdom. International Journal of Nautical Archaeology 43(2), 239-78.

Overmeer, A. B. M. 2007. Searching for the missing link? A research on clinker build ships in the 15th and 16th centuries, in E. Gehring (ed.), SOJA-bundel 2006, Symposium voor Onderzoek door Jonge Archeologen, 
Amsterdam, 63-72. Groningen: Stichting Onderzoek Jonge Archeologen.

Pomey, P., Kahanov, Y. and Rieth, E. 2012. Transition from shell to skeleton in ancient Mediterranean shipconstruction: analysis, problems, and future research. International Journal of Nautical Archaeology 41(2), 235-314.

Reinders, R. 1979. Medieval ships: recent finds in the Netherlands, in S. McGrail (ed.), The Archaeology of Medieval Ships and Harbours in Northern Europe. International Symposium on Boat and Ship Archaeology at Bremerhaven in 1979. BAR International Series 66, 35-43. Oxford: Archaeopress.

Rieck, F. 2013. Funde von Schiffen und Schiffsteilen aus dem Nydam-Moor 1859-2011, in A. Rau (ed.), Nydam Mose 4, 1-145. Århus: Universitetsforlag.

Rieth, E. 2013. L'epave de la première moitié du XVe siècle de la Canche à Beutin (Pas-de-Calais). Revue du Nord hors série Archéologie 20, 2013. Villeneuve d'Ascq: Université Charles-de-Gaulle, Lille.

Schutten, G. J. 2004. Verdwenen schepen. De kleinen houten beroepsvaartuigen, vrachtvaarders en vissersschepen in de Lage landen. Zutphen: Walburg Pers.

Siegloff, E. 2004. Studien zu den Sintelfunden an der
Schleswiger Landenge. Unpublished Diploma thesis, Kiel University.

Soberón, M., Pujol, M., Llergo, Y., Riera, S., Juliá, R. and Domínguez, M., 2012. El Barceloneta I. Una embarcación medieval a tingladillo en Barcelona. Revista de Estudios Marítimos des País Vasco 7, 411-22.

Stanek, A. 2011. The Wittenbergen Wreck: An example of flush planked shipbuilding in northern Europe. Unpublished Masters thesis, Syddansk Universitet.

Svenwall, N. 1994. Ett 1500-tals fartyg med arbetsnamnet Ringaren. Unpublished PhD thesis, Stockholm University.

Varenius, B. 1992. Det nordiska skeppet. Teknilogi och samhällsstrategi $i$ vikingatid och medeltid. Stockholm Studies in Archaeology 10. Stockholm: Stockholms Universitet.

Vogel, W. 1915. Geschichte der deutschen Seeschiffahrt, vol. 1. Berlin: Georg Reimer.

Weski, T. 1999. The Ijsselmeer type. Some thoughts on Hanseatic Cogs. International Journal of Nautical Archaeology 28(4), 360-79.

Wolf, T. 1986. Tragfähigkeiten, Ladungen und Maße im Schiffsverkehr der Hanse. Cologne: Böhlau. 